\title{
Pengaruh Aktivitas Eksklusif Sempadan Pantai Bagi Kehidupan Masyarakat Di Pantai Double-Six
}

Gracia Luciana Handayania, 1, Putri Kusuma Sanjiwania, 2

${ }^{1}$ skripsigracialh@gmail.com, ${ }^{2}$ kusumasanjiwani@unud.ac.id

a Program Studi Sarjana Destinasi Pariwisata, Fakultas Pariwisata, Universitas Udayana, Jl. Dr. R. Goris, Denpasar, Bali 80232 Indonesia

\section{Abstract}

The tourism sector has a lot of impact on the economy of Badung Regency, especially in the Province of Bali even though, the ongoing activities of exclusive beach borders that are used for public spaces cannot yet be tolerated.As for the scope of the research, there are exclusive activities carried out by tourism entrepreneurs in the area of the beach that are used for exclusive activities, such as: tourist activities, community activities, activities of businesses in the field of tourism, viewpoints of tourists, viewpoints of people who live in villages. Seminyak customary, along with the regency-Badung regulations regarding exclusive activities on the coastline at DTW Double-Six Beach. techniques in collecting data in this study include observation, interviews, literature studies, and also documentation. The purposive sampling method is the technique of determining the informants used. The technique used in the cultivation of the report is a qualitative descriptive analysis. Exclusive activities at Sempadan Pantai carried out by tourism entrepreneurs include: K-Resto, Blue9Beach, The Sand Beach Bar\&Grill, Capil Beach Grill\&Bar, D’Joglo Beach Bar\&Restaurant, The-Camplung Bar\&Restaurant, La-Plancha, Bali Juice-Park, Taris-Bali, dan Chiringuito Bar-GrillRestaurant. This exclusive activity also gives effect to the people who live around the Smeinyak Indigenous Village community, among others in terms of language, how to dress, building a business place, music flow, food and drink, and so forth. Tourism that comes is also presented with attractions that are present / modern

Keyword: exculsive activity, impact, beach border, public area, double six beach

\section{PENDAHULUAN}

Beragam cara terkait dalam pembangunan sektor pariwisata sebagai primadona dilaksanakan oleh pemerintah RI pada program pembangunan nasional (Nawacita Jokowi-JK). Salah satunya yaitu Peraturan Presiden RI No. 26 Tahun 2016 mengenai Pembebasan Visa Kunjungan yang telah dibagikan untuk 169 negara dengan agenda dari pembangunan 10 destinasi wisata prioritas. Sepuluh Bali Baru sebagai brand dengan mengupayakan target kunjungan wisatawan mancanegara sebesar 20 juta orang (Mahagangga, dkk., 2018).

Sasaran pokok pembangunan dari sektor pariwisata disampaikan secara jelas yaitu Nawacita pada poin ke-6 dan ke-7 yang berbunyi: (6)Menciptakan bangsa Indonesia yang progresif bersama juga menghidupkan kembali bangsa lain serta melaksanakan eskalasi (peningkatan) daya produksi masyarakat dan persaingan di pasar Universal; (7) Penggerakan sektor ekonomi dalam negeri melalui pemanfaatan ke-strategisan. (Kementerian Perencanaan Pembangunan Nasional, 2017).

Perkembangan pariwisata nasional menunjukkan Provinsi Bali memiliki kemampuan strategis dalam pembangunan sektor pariwisata. Perkembangan pariwisata Bali sebagai turismemorfosis yang memiliki usia lebih dari seratus tahun membuktikan pembangunan sektor pariwisata Bali adalah andalan pembangunan bagi pertumbuhan pendapatan asli daerah dan kesejahterahaan masyarakatnya (Anom, dkk., 2017).
Bali menjadi ukuran pariwisata Indonesia sebagai analisis benchmarking suksesnya pembangunan pariwisata nasional. Problematika pembangunan pariwisata di Bali dan solusinya, dijadikan perbandingan dalam upaya perencanaan pariwisata di berbagai daerah lainnya.

Sebagai aset dari pariwisata-Indonesia yang sudah diketahui oleh khalayak dunia. Bali juga dikenal dengan julukan "the islands of Gods" menjadikan bali sebagai penyokong wisatawan-mancanegara di Indonesia. Tahun-2017 angka kunjungan wisatawan mancanegara ke Indonesia mencapai 5.697.739 dengan presentase $40.58 \%$ wisatawan mancanegara mengujungi Provinsi Bali.

Pariwisata di Bali tampak sangat positif dan profitable. Tetapi, jika dikaji dari perspektif berbeda profitable berpotensi melahirkan kesenjangan. Perkembangan pariwisata Bali dengan pertumbuhan ekonomi yang pesat, spontan menciptakan persaingan investasi dalam iklim bisnis industri pariwisata khususnya akomodasi pariwisata hotel dan restoran.

Gubenur Provinsi Bali sudah melangsungkan demobilisasi sementara pada pembangunan hotel di tiga daerah, yaitu di Denpasar, Badung, dan Gianyar dan kemudian ditarik kembali padatahun 2016 lalu. Melalui Surat Gubernur Bali Nomor 570/1665/BPM mengenai Pemberhentian secara Sementara pada Pendaftaran Penanaman Modal dalam Bidang Usaha Jasa Akomodasi Pariwisata diberlakukan sejak tanggal 5 Januari 2011 dijadikan opsi pilihan dalam pencegahan pengalihan fungsi dari lahan serta kompetisi harga pada pelaku bisnis akomodasi. 
Rumitnya persoalan pariwisata konsekuensi oversupply hotel berlangsung di KabupatenBadung. Kabupaten Badung yang memiliki julukan "the soul of Bali" ini belum pernah terlepas daripada pandangan khalayak ramai. Badung adalah kabupaten yang sangat mengandalkan sektor pariwisata. Lebih-lebih di tahun 2017lalu, penilaian dari PAD Kabupaten Badung sebesar Rp4.172.457.395.825,25 dengan banyak mengantongi Pajak Hotel dan Restoran (PHR). Nilai tersebut melebihi PAD dari Provinsi Bali bernilai Rp3.398.472.278.000,00.. bukan sekedar hal tersebut, setiap tahunnya, Kabupaten Badung juga melakukan transmisi membagi pemasukan kepaada kabupaten lainnya yang berada di Provinsi Bali dengan tujuan menyokong ekonomi daerah-daerah disana. Pada tahun lalu, besaran transmisi pembagian perolehan dari Kabupaten Badung untuk Pemerintah daerah lain sejumlah Rp401.616.375.862,37 (BPS Provinsi Bali, 2018; badungkab.go.id).

Ekspansi kepariwisataan KabupatenBadung berada pada tahapan terus-menerus berawal dariKuta dan pada jaman sekarang ini telah merambah area Seminyak, mewariskan modifikasi yang signifikan terhadap persona pariwisata. Bukan hanya sekedar bisnis akomodasi, bisnis jasa makanan dan minuman juga berkembang dengan pesatnya dan telah menjadi primadona di area tersebut. Pembangunan pariwisata ini, telah melahirkan pengusaha-pengusaha pada sektor pariwisata menomorsatukan kepribadian abdi mereka pada pemanfaatan area-area umum. Mereka pun sebagai pelaku pariwisata memulai dalam melaksanakan aktifitas eksklusif. Aktifitas eksklusif terjalin di Pantai Double-Six di sepanjang bibir pantai/sempadan pantai. Aktifitas eksklusif oleh parapengusaha pariwisata di sempadan pantai merupakan tingkatan persoalan kemasyarakatan yang mengarah pada permasalahan terpendam/laten, dimana permasalaha tersebut bersifat manifest atau sudah terlihat jelasmkendatipun akan ada masanya dimana permasalahan dimasyarakat itu timbul kepermukaaan yang dapat menjadi sebab masyarakat melawan pada aktifitas eksklusif yang silaksakana para pengusaha pariwisata.

Sanjiwani (2016) serta Irnawan (2018) menjumpai praktik privatisasi sempadan pantai yang telah dilaksakanan oleh para pengusaha akomodasi di banyak area di Bali. Realisasi dari privatisasi sempadanpantai ini dilaksanakan dengan tipu daya demi memberi jaya layanan/servis terbaik serta dapat menumbukan rasa puas dari wisatawan. Implikasi dari kegiatan tersebut akhirnya membuat sempadan/pinggiran pantai di sebagian lokasi semestinya bisa di nikmati masyarakat umumnya pada saat ini semata-mata bisa di nikmati golongan eksklusif yang dapat dinamai juga yaitu elite atau wisatawan. Kegiatan ini lazimnya semarak tumbuh di Kabupaten Badung, akuratnya pada area Nusa Dua (Kawasan ITDC dan Tanjung Benoa), Seminyak,Bukit Ungasan,dan daerah Canggu.
Sektor pariwisata mengantongi banyak impak pada ekonomi Kabupaten Badung, lebih-lebih Provinsi Bali kendatipun, terus-menerus aktifitas eksklusif sempadan pantai yang digunakan untuk tempat khalayak belum bisa ditoleransi. Peristiwa tersebut tidak dapat dipungkiri dari pengambilan hak khalayak masyarakat khususnya masyarakat yang tinggal di sekitar area tersebut. Niscaya dipahami mengenai dunia kepariwisataan, selaku pemerintah, selaku swasta, serta khalayak masyarakat disekitar area merupakan stakeholders pariwisata berdiam di posisi seimbang. Mereka-mereka ini ialah poin utama dalam kepariwisataan, tidak ada yang unggul maupun diunggulkan. Korelasinya dengan aktifitas eksklusif sempadan pantai memperlihatkan bahwa aktifitas ini seakan-akan menepikan masyarakat lokal serta melangsungkannya menjadi tujuan pariwisata.

Maka dari itu, niscaya melangsungkan analisis dari aktifitas eksklusif di sempadan pantai yang dapat menjadi bahan pertimbangan untuk pemerintah dalam mengintreprestasikan peraturan kebijakan dalam pendayagunaan area umum dan juga bisa memberi pemahanan kepada masyarakat yang memiliki hak tersebut. Dengan begitu, hendak terbina persamaan pengertian dan sudut pandang pada pembangunan pariwisata yang melibatkan tiga komponen sonder memberatkan salah satu komponen tersebut.

\section{METODE PENELITIAN}

Penelitian ini terletak di Pantai Double-Six, Seminyak, Kabupaten Badung,Bali terkhususnya berada di jalan Camplungtanduk. Ruang lingkup penelitiannya ialah aktifitas eksklusif yang dilakukan pengusaha pariwisata di kawasan sempadan pantai yang di gunakan untuk aktifitas eksklusif antara lain : kegiatan wisatawan, kegiatan masyarakat, kegiatan dari usaha dalam bidang kepariwisataan, sudut pandang dari wisatawan, sudut pandang masyarakat yang tinggal di Desa Adat Seminyak, beserta peraturan Kabupaten Badung mengenai aktifitas eksklusif di sempadan pantai di DTW Pantai DoubleSix.

Penelitian menggunakan paradigma penelitian kualitatif (Anom, dkk., 2019). Sumber data primer di lapangan dan data sekunder sebagai rujukan menjadi fokus penelitian. Teknik penentuan sample menggunakan purposive-sampling sebagai informan yang memberikan informasi untuk diolah menjadi data (Sugiyono, 2010). Teknik pengumpulan data di penelitian ini meliputi observasi (Suryawan, dkk., 2017), wawancara (Bungin, 2007), studi pustaka, dan juga dokumentasi (Sugiyono, 2010). Teknik analisis data menggunakan analisis data kualitatif (Muhadjir, 1996) dengan penyajian data secara deskriptif kualitatif (Arikunto, 2010).

\section{HASIL DAN PEMBAHASAN}

Pantai Double-Six biasa diketahui juga dengan nama Seminyak Beach merupakan satu dari 
banyaknya DTW yang lumayan kondang digolongan wisatawan yang berwisata di Bali.Pantai Seminyak berada segaris dengan Pantai Kuta serta Pantai Legian. Panjangnya pesisir/tepi pantai sekitar 1.9kilometer. Perbatasan selatan maupun utara pada pantai ini merupakan aliran sungai yangmana usaha pariwisata ujung selatan/kidul ialah K-Resti untuk ujung utara ialah Casa Luna Villa Seminyak. Pantai Double-Six memulai untuk dibenahi serta dikendalikan dari Desa Adat. Desa Adat pun mengatur penanggungjawab untuk penanganan dari pengelolaan pantai dan parapengusaha pariwisata sejak tahun 2003. Di tahun 2004 pengelolapun membentuk satuan kerja kebersihan yang memiliki tugas yaitu mendisiplinkan serta memelihara area Pantai Double-Six. Ditahun 2007 yang lalu, dibentuklah SATGAS untuk pantai yang dapat disebut PENERTI.

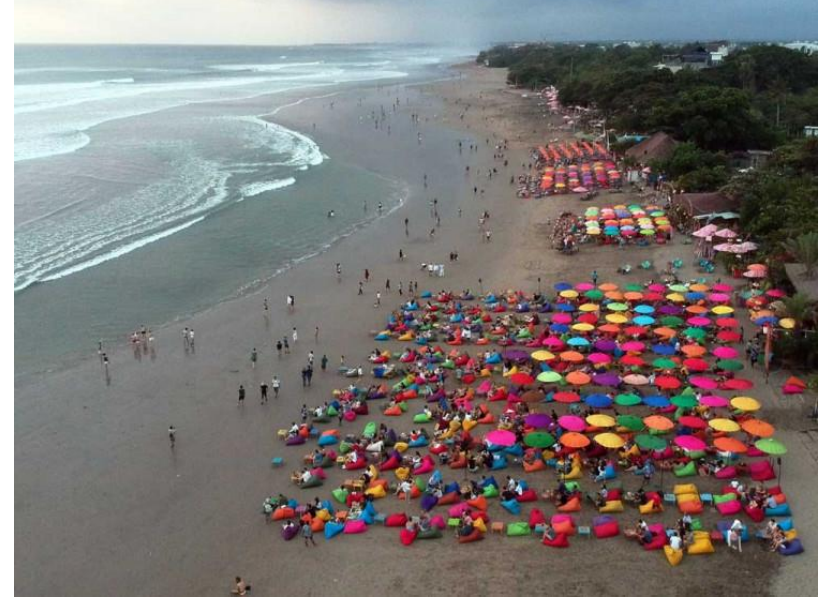

\section{Gambar1 Double-Six-Beach, 2019}

\section{Sumber:www.covesia.com}

Sejauh sembiran pantai Double-Six, wisatawan dipertunjukn banyak aktivitas yang bisa dilakukan di alam terbuka antara lain selancar, renang, bisa juga menikmati matahari terbenam dengan duduk du psair pantai ataupun bean bag sambil menunggu keindahan matahari turun/terbenam. Disempadan Pantai Double-Six, ada beberapa usaha pariwisata dipecah 2 antara lain kelompok warung pantai dan juga pedagang pantai. Pengertian dari warung pantai terdiridari cafe, bar, serta restaurant Terdapat sepuluh usaha pariwisata di Pantai Doublesix antara lain : K-Resto, Blue9Beach, The Sand Beach Bar\&Grill, Capil Beach Grill\&Bar, D'Joglo Beach Bar\&Restaurant, The-Camplung Bar\&Restaurant, LaPlancha, Bali Juice Park, Taris-Bali, dan Chiringuito Bar-Grill\&Restaurant. Yang disebut juga Pedagang payung memiliki jumlah 179 (seratus tujuh puluh Sembilan) tempat usaha yang terbagi menjadi 5 kelompok yaitu Pedagang Payung/Longcer, Pedagang Makan-Minum, Souvenir, Kain serta pijat refleksi, dan Pedicure / plat ikat rambut. beranekaragam parausah di sempadan Pantai
Double-Six, wisatawanpun tidak mengkhawatirkan bkebutuhan ketika berwisata di tempat tersebut.

Pantai Double-Six dipecah dijadikan 2(dua) area antara lain economi zone dan ceremony zone. Dimana di economy zone adalah area yang digunakan oleh para pengusaha pariwisata di sempadan pantai. Pada ceremony zone, area ini dipergunakan untuk Melasti oleh masyarakat di kelurahan Seminakerutama yang berada di Desa Adat Seminyak. Kegiayan yang dilakukan oleh wisatawan di pantai tersebut ialah berselancar, voli pantai, renang, bungeejumping, bersemayam rileks di beanbag ditemani paying warna beranekaragam yag berada di kafe dan restorannnya dan sekedar bersemayam di bibir-pantai berlapiskan pasir dan mengenyam memandang matahari terbenam.

Selain terdapat egiatan dari wiskal maupun wisman di DTW Pantai Double Six, ada pula kegiatan yang dilakukan oleh masyarakat Desa Adat Seminyak. Penduduk dari Desa Adat Seminyak sebagian banyak memiliki pekerjaan yang dilakukan di DTW Pantai Double-Six antara lain: mempunyai bisnis bar\&restaurant di DTW Pantai Double-Six, begitupun pekerjaanya di tempat itu, yaitu aparat keamanan, pengasong kaki lima, pekerjaan di bagian akomodasi dan transportasi, serta banyak kios mini yang memperdagangkan bermacammacam cenderamata, tas, baju serta lukisan.

Profil usaha pariwisata di DTW Pantai Doublesix:

\section{a. La-Plancha}

Waktu buka : 08.00-01.00WITA

A la-plancha berasal dari bahasa panyol yang berarti di panggang diatas piring logam. Pengucapannya adalah "ah la plahnchah", yang memiliki makna seperti yang disebutkan pada kalimat sebelumnya. Pada dasarnya resep yang digunakan adalah cara masak yang tradisional diatas pelat/logam yang berbentuk bulat dan rata/datar.

La-Plancha berada tepat di sental panorama bali yang mana antara laut dan hutan. La-Plancha buka sejak tahun-2010 dengan gaya restoran Chiringuito dan yang menjadi yang pertama di Pantai Seminyak.

\section{b. D'Joglo Beach Bar\&Restaurant}

Bar serta restoran merupakan salah satu bisnis yang ada di DTW Pantai Double-six. Restoran ini menyediakan jamuan makanan. Resto ini dibangun dengan konsep joglo yang menggunakan kayuu sebagai bahan utama pembangunan. Restoran ini mempunyai dua puluh lima (25) pegawai.

\section{c. K-Resto}

Waktu buka : 08.00-00.00WITA

K-Resto merupakan sebuah restoran yang mana italia cuisine menjadi menu utama. K-Resto ini juga mencawiskan vegetarian food yang mana KResto terletak di paling ujung arah ke selatan. 
d. Blue-9-Beach Bar\&Restaurant

Wakti buka: 08.00-00.0WITA

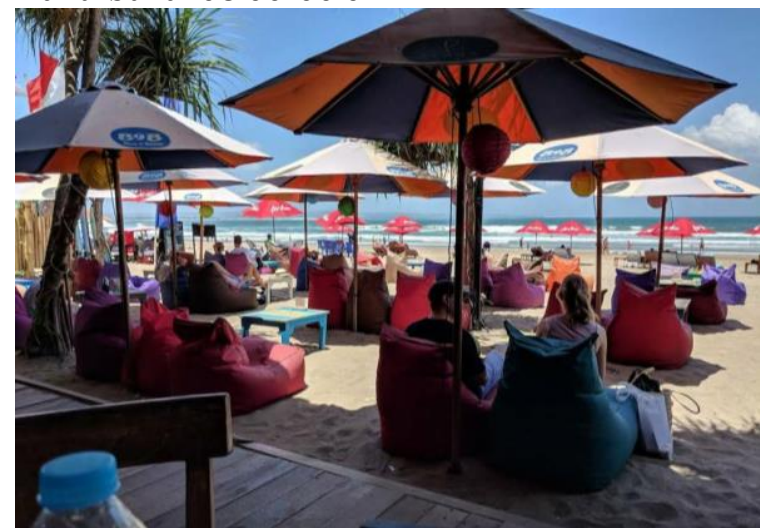

Gbr3.6 Blue-9-Beach Bar\&Restaurant

Sumber dokumentasi pribadi,2019

Bisnis pariwisata yang satu ini pada menunya menjual minuman yang berasal dari Bali yang dapat disebut dengan Traditionall Balinessee Cocktail.

e. The Sand Beach Bar \& Grill

Waktu buka : 08.00-00.00WITA

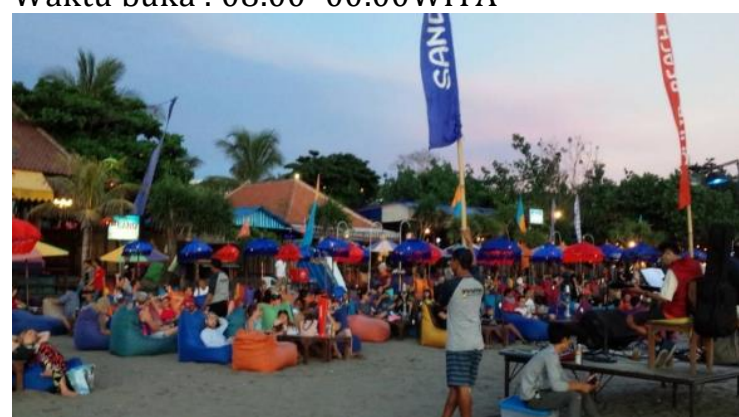

Gbr3.7 The Sand Beach Bar\&Grill

Sumber dokumentasi pribadi,2019

Bisnis pariwisata ini mengangkat tema yang sama dengan usaha yang pada umumnya dii DTW Pantai Double-six. Beranekaragaman makanan dihidangkan di tempat ini.

f. Capil Beach Grill\& Bar

Waktu buka: 08.00-00.00WITA

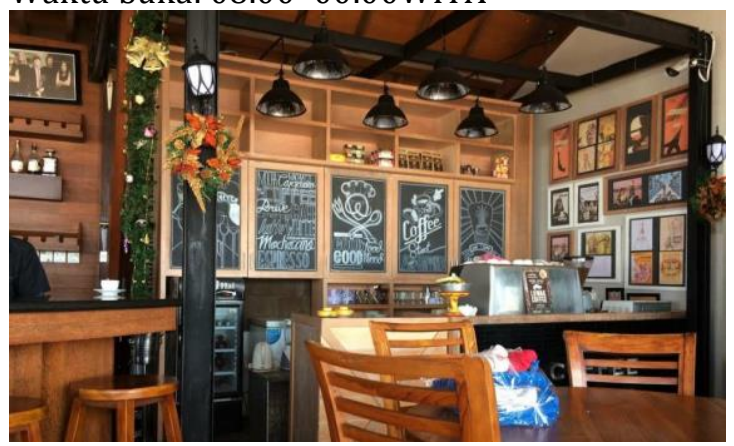

Gbr4.8 Capil Beach Grill\&Bar

Sumber dokumentasi pribad,2019

Restoran bertema Amerika dengan menu utamnya adalah Kopi.

g. Bali Juicee Park

Waktu buka: 08.00-00WITA
Usaha dalam bidang pariwisata ini termasuk pada pedagang warung di DTW Pantai Doublesix. Masakan yang di sajikan oleh pengusaha ini dimulai dari Indonesian taste hingga western taste.

h. Taris-Bali

Waktu Buka:: 08.00-00.00WITA

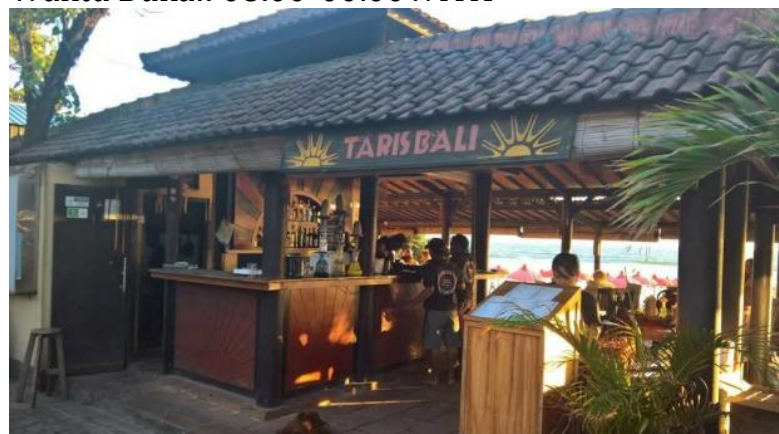

Gbr3.10 Taris-Bali

Sumber dokumentasi pribadi,2019

Lokasi dari usaha ini berada paling utara di jalan Camplung Tanduk.

i. Chiringuito Grill-Bar\& Restaurant

Waktu buka: 08.00-00.00WITA

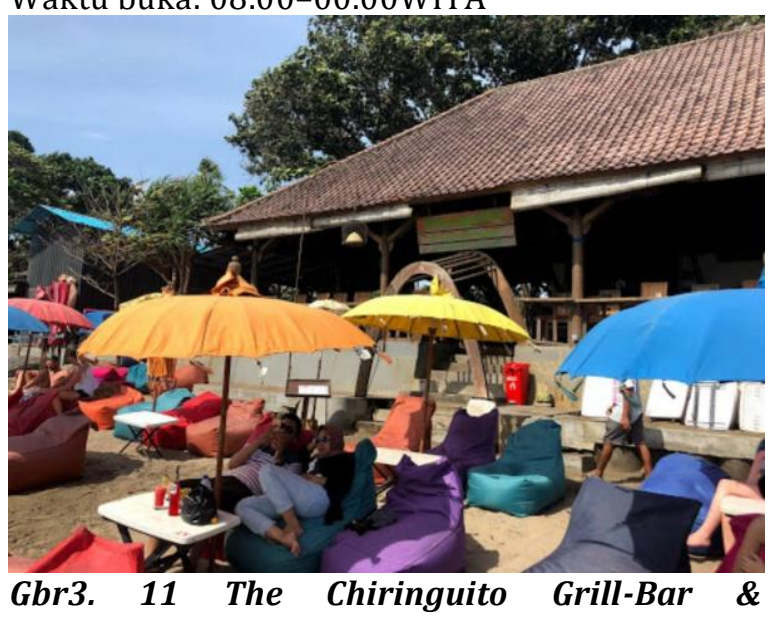

Restaurant

Sumber dokumentasi pribadi,2019

Restoran ini menyedikn masakan vegetarian.

Mayarakat yang hadir, dewasa, serta bermukim di Bali pasti tau dan menerima kultur di masyarakat. Kegiatan yang saat dilakukan tetap dilaksanakan yaitu ceremony masyarakat beragama Hindu yang disebut Melasti. Upacara ini merupakan sebuah upacara pembersihan dalam diri untuk menyongsong hari raya Nyepi yangmana dilaksanakan masyarakat berkepercayaan hindu. Ceremony ini dilaksanakan untuk membuang limbah alam memakai air kehidupan. Ceremony ini dilakukan di pesisir pantai yang bertujuan untuk membersihkan diri dari semua perilaku buruk yang terjadi di masa lampau dan menghanyutkannya ke laut. Agama Hindu, sumber air layaknya air danau dan air lat yang dipercaya sebagai air kehidupan (tirta amerta). Selain dilaksanakannya 
persembahyangan, ceremony Melasti juga salah satu penjernihan dan penyucian benda keramat yang dimiliki oleh pura (pralingga atau pratima Ida Bhatara dan semua perlengkapannya). Bendakeramat tersebut dibawa keliling desa. Aktivitas tersebut dilaksanakan bertujuan untuk memurnikan desa yang ditinggali. Yang mana, ceremony itu masyarakat membuat perkumpulan yang bertujuan ke titik mata-air yakni danau dan laut. Perkumpulan tunggal dari kawasan yang sama. Semua anggota memakai pakaian berwarna putih. Para petinggi agama mengelilingi dan merecikkan air murni untuk semua anggota yang menghadiri dan juga staff persembahayangan setelah itu, dilaksanakan penghamburan asap dupa sebagai entitas mensakralkan. Dilaksanakannya Melasti ceremony digenapi beragam jamuan untuk lambang Trimurti, 3 dewa di kepercayaan Hindu yakni Wisnu,Siwa, serta Brahma, Jumpana, dan Dewa Brahma. Masyarakat melaksanakan Melasti ceremony berlokasi disamping Blue9 Beach Bar\&Restaurant, ada gapura ganda yang tinggi yang dijadikan petunjuk bahwa area tersebut adalah ceremony zone.

Aktivitas eksklusif di sempadan pantai antara lain para-pengusaha di sempadan pantai memfasilitasi beanbag disertai payung beranekaragam warna. Aktivitas eksklusif ini berlangsung pada saat wisman ataupun wislok tiba di DTW Pantai Double-six tanpa membeli/menjajakan uangnya di café atau restoran pada jam operasionalnya dimulai dari jam 08.00 WITA hingga malam hari sampai-sampai tidak leluasa untuk tinggal di sempadan pantai karena lokasi yang sepatutnya dipergunakan untuk khalayak banyak/umum dan dipergunakan oleh café dan restaurant menempatkan beanbag bagi wisman dan wislok yang bertandang kesana. Sekarang ini, Seminyak memerankan sebagai kawasan di Bali yang jumlah wisatannya cukup besar sesudah Legian serta Kuta. Karena banyaknya kunjungan wisatawan tersebut, para-pengusaha dibidang pariwisatapun secara besar-besaran melantaskan advertensi pada ekspansi komoditasnya. Aktivitas eksklusif adalah efek dari kegencaran para-pengusaha pariwisata di Pantai Double-six dalam melangsungkan wisatawan terbujuk dan pada akhirnya berbelanja. Dibagian ini, maksud dari para pengusaha pariwisata merupakan kelompok pedagang warung. Bertambahnya jumlah wisatawan pula membuat para pengusaha tersebut secara acuh tidak peduli terhadap sempadan pantai yang dipergunakan sekehendakanya hingga ke bibir dari pantai dan aktivitas tersebut kurang serasi dengan peraturan yang telah dibuat pemerintah. Begitupun, budaya tradisional Bali juga akan lenyap dengan seiringnya waktu apabila tidak dijaga oleh para pengusaha warung di Pantai Duble-six. Para pedagang warungpun ikut pada mode yang mana dapat memuaskan wisatawan yang dapat dilihat dari struktur bangunan, minuman, fashion style, makanan, musik, serta bahasa yang digunakan.

Aktivitas eksklusif di sempadan pantai yang dijalankan oleh para pedagang warung di DTW Pantai Double-six mendatangkan pengaruh pada masyarakat khususnya masyarakat yang tinggal di Desa Adat Seminyak. Pendapat Islami ditahun 2003, pengaruh/implikasi merupakan suatu terjadi karena ada proses. Pengaruh/implikasi merupakan akibat dimasa yang akan datang, dan dicerminkan sebagai impak dari tindak-tanduk. Sekarang, aktivitas eksklusif ini merupakan sebuah konflik/ permasalahan yang bersifat laten atau tidak terlihat. Konflik/permasalah laten ini bisa dikenal juga dengan konflik tertutup. Pegertian dari konflik tertutup adalah satuperihal yang mana didalamnya memiliki berlimpah permasalahan, yang sifatnya terselubung/tidak terlihat dan diperlukan untuk di perlihatkan ke permukaan yang harus diselesaikan dan dirampungkan sehingga tidak semakin menjadijadi masalah tersebut. Aktivitas di masyarakat yang terlihat setimbang dan proporsional belum menjadi agunan bahwa di kehidupan dari masyarakatnya tak ada pergesekan dan perselisihan.

Aktivitas di masyarakat Desa Adat Seminyak tentu seiring berjalannya waktu mengalami alterasi. Aktivitas eksklusif yang dilakukan oleh para pengusaha pariwsiata pada kelompok pedagang warung mengususng pengaruh yang positif hingga pengaruh yang negative di masyarakatnya sendiri. Salah satu dari konsekuensi yang bersifat positif adalah dengan adanya pariwista di Seminyak ini sendiri masyarakatnya dapat bekerja dalam industry pariwisata dan bahkan dapat membuka lapangan pekerjaan kepada masyarakat Desa Adat Seminyak hingga penduduk yang tinggal di Bali. Peningkatan ekonomi di masyarakatpun menjadi baik adanya. Ada pengaruh positif tentu juga ada pengaruh negative yang ditimbulkan dari aktivitas eksklusif sempadan pantai yang dapat menjadi titik permasalahan apabila tidak dengan cepat ditangani. Konsekuensi negatifnya antara lain visi misi dari pariwisata bali dimana pengembangan kepariwisataan layaknya sesuai yaitu dikembangkannya pariwisata berbasis kerakyatan, perbaikan prasarana, eksplorasi terobosan, pendemokrasian pariwisata dalam memberdayakan masyarakat, meningkatkan wisata berbasis budaya dengan terintegrasi, mewujudkan kondisi yang mendukung, menjalankan pelestarian yang dapat memotivasi kelompok pariwisata juga para pelakunya yangmana berdedikasi pemeliharaan budaya. Di DTW Pantai Double-six belum ada penyajian atraksi pariwisata berunsur budaya kepada wisatawan yang datang. Rupa-rupanya, para pengusaha pariwisata di Pantai double-six menyuguhkan bukan musik khas tradisional Bali dan mengakibatkan kaum muda yang tinggal disekitar pantai mulai menyukai music beraliran 
modern untuk mengikuti mode yang sedang berkembang. Di kawasan pantaipun jika dipandang, bangunan-bangunan yang ada disana belum ada unsure dari bali yang ditunjukan tentunya wisatawanpun tidakan tau akan bagaimana bangunan tradisional Bali yang sebenarnya yang tidak mereka rasakan di Pantai double-six. Dilihat dari pakaian/sandang yang digunakan oleh para pengusaha dalam kelompok oedagang warung serta pedagang payung mengenakan pakaian modern yang tidak menampilkan pakaian budaya bali. Perolehan hasil dari tanya jawab antara peneliti dengan para-pengusaha pariwisata yang ada di Pantai Double-six, empu dari pedagang warung di DTW Pantai Double-six merupakan masyaarakat yang tinggal dan sesuai di kelurahan seminya berdasarkan Kartu Tanda Penduduk. 95(Sembilan puluh lima) daripada 179 (seratus tujuh puluh Sembilan) pedagang-payung dipecah menjadi 5(lima) kelompok merupakan masyarakat yang tinggal dan hidup di desa seminyak tersebut sedangkan selebihnya merupakan masyarakat diluar desa atau elurahan seminyak. Mata pencaharian di economy zone diutamakan dari masyarakat yang berdomisili. Terdapat pula kebijakan perjanjian bisnis untuk pedagang payung serta pedagang warung. 2(dua) penanggungjawab yang bertugas dalam mengawasi ketertiban dari pedagang di Pantai Double-six. Krusial diteguhkan kembali tentang aktivitas eksklufis yang mana jumlah kunjungan wisatawan yang semakin melonjak, parapengusaha di pantai tidak menentukan batas dari jumlah kunjungan wisatawan dan ruang gerak dari wisatawan yang tidak berbelanja-pun semakin sempit karena sempadan pantai digunakan oleh wisatawan lain yang berbelanja. Selain wisatawan juga adapula masyarakat tidak dapat berada pada kawasan/daerah yang ada beanbag sementar itu seharusnya itu merupakan are public untuk dapat pula dinikmati oleh masyarakat ataupun khalayak ramai.

Permasalahan pun semakin lama akan timbul pada masyarakat dengan para pengusaha pariwisata di Pantai Double-six disaat masyarakat telah sadar terhenti ada saat Melasi ceremony pada waktu jumlah wisatawan yang banyak ke Pantai Double-six. Kejadian ini bisa terjadi pada saat highseason yang bersamaan dengan Melasti ceremony yang mana ruang gerakpun semakin sempit adanya dan bisa juga mererasaa dibatasi. Makan dari itu akan terjadi protes di masyarakat.

Pengatuh negative dari aktivitas eksklusif itu haruslah disegerakan untuk di tertibkan supaya tidak berlanjut yang dapat menjadi permasalahan yang rumit. Hendaklah dalam peninjauan kembali peraturan/kebijakan menga=enai aktivitas yang seharusnya dilakukan di sempadan pantai hingga aktivitas yang tidak seharusnya ada/dilakukan.

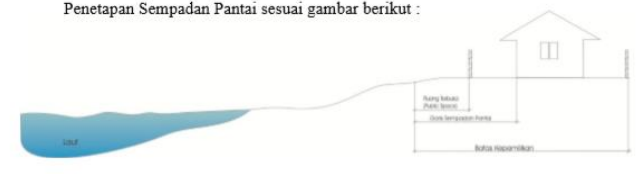

\section{Gambar 2 Penetapan peraturan sempadan Pantai}

\section{Sumber Peraturan Pemerintah Kabupaten Badung}

Peraturan dari Pemerintah Kabupaten Badung ialah kebiakan tertera yang mengandung membahas ketetapan resmi daripada formasi, dan bersifat mewajibkan. Adanya peraturan tersebut mengarahkan integritas agar menumbuhkan nilaii yang baik dan baru. Peraturan tersebut ini dijadikan barometer untuk aktivitas eksklusif ada ada di DTW Pantai Double-Six, Kabupaten Badung, Bali. Pemerintah sendiri mempunyai wewenang secara maksimal atas kawasan pantai.

Pada pokok yang kesatu dijelaskan pada darat sejauh pinggiran perairan/laut, jarak minimum untuk terdapat aktivita sendiri adalah 100 meter diawali titik-pasang air laut dan penggunaan dari sempadan pantai di DTW Pantai Double-Six sekitar 30 meter dari titik pasang air laut. Pada pokok yang bertuliskan Ruang kawasan Sempadan Pantai ialah kawasan terbuka bagi konvensional perta konstruksi yang diperbolehkan ialah konstruksi akomodasi pendukung pariwisata bersifat nonpermanen dan modis, pembangunan yang bersifatnya umum terpaut mengenai sosialkeagamaan, pembangunan kegiatanperikanan tradisional serta pelabuhan, pembangunan sebagai pengawas pantai, pembangunan yang bertujuan dalam pengamatan pengamanan pantai dari abrasi/pengikisan tanah, pembangunan mengevakuasi dari adanya bencana, serta bangunan untuk proteksi dan kenyamanan. Pembangunan yang ada di sempadan Pantai Double-Six dari pengasong payung tak semuanya menerapkan pembangunan melihat keamanan pantai dari abrasi, pembangunan evakuasi bencana, dan pembangunan proteksi serta kenyamanan. Dan pembangunan tersebut dilangsungkan layaknya restoran pada umumnya. Di pokok setelahnya, aktiviitas ritual riligiositas. Pantai Double-six dimanfaatkan bagi masyarakat melaksanakan Melasti. Ceremony dilaksanakan di ceremony zone Pantai Double-six. Pelaksanaan upacara tersebut dilakukan secara bergilir-gilir antara msyarakat desa adat dengan masyarakat kelurahan.

Peraturan Pemerintah Kabupaten Badung patut ditaati dan dilakukan bagi para pelaku pariwisata. Aktifitas eksklusif merupakan agresi mesti cepat kedapatan dan tergarap permasalahannya supaya tidak ada kejadian yang menyimpulkan di DTW Pntai Double-Six terdapat masalah aktifitas eksklusif tidak tidak diikuti oleh daya tarik yang lainnya. Aktifitas eksklusif yang di jalankan oleh sepuluh 
pengusaha pariwisata, niscaya mengemban impresi kepada kehidupan masyarakat di Desa Adat Seminyak. Secara potensial akan ada timbul masalah dimasa yang akan datang. Aktifitas eksklusif dapat menghadirkan perselisihan antara masyarakat dengan pengusaha dibidang kepariwisataan dan bisa juga akan terjadi perselisihan oleh sesama pemilik usaha.

Aktifitas eksklusif sempadan pantai yang dilaksanakan oleh para-pengusaha/pemilik bisnis dalam pengkajian, berlokasi di sempadan pantai doble-six tepatnya di Desa Adat Seminyak. Gelagat aktifitas eksklusif sempadan pantai yang terjadi didouble-six haruslah disegerakan untuk menjadi tertib dalam memencilkan aktifitas yang sama yang dapat dilaksanakan di sempadan pantai lainnya. Aksi koheren pemerintah pada peraturan mengenai aktifitas eksklusif sempadan pantai dapat dibilang jauh ari adanya kata perfek yang dapat dibuktikan masih ada aktifitas eksklusif di sempadan pantai Double-six. Aktifitas eksklusif pada jaman sekarang berjalan dengan tenang dan didamkan dan belum sesuai dengan peraturan perundangundangan yang seharusnya. Serta belum ada sanksi/penalti yang mengharuskan secara gamblang dalam penindaklanjutan siapasaja yang masih melaksanakan aktifitas eksklusif sempadan pantai sehingga aktifita ini masih saja terjadi dan tetap berlanjut sampai saat sekarang ini.

\section{KESIMPULAN}

Simpulan mengenai pembahasann yang sudah dijawab dan dijelaskan adanya aktivitas eksklusif di Sempadan Pantai yang dilakukan oleh para pengusaha pariwisata antara lain : $K$ Resto, Blue9Beach, The Sand Beach Bar\&Grill,

\section{DAFTAR PUSTAKA/REFERENSI}

Anom, M.Par., Dr. Drs. I Putu dan Mahagangga, S. Sos., M.Si., I Gusti Agung Oka. Handbook Ilmu Pariwisata Karakter dan Prospek. Jakarta: Prenada Media (Divisi Kencana)

Abidin, Yunus. 2012. Pembelajaran Bahasa Berbasis Karakter. Bandung:PT Refikaa Aditama.

Arikunto, S. (2010). Metode Peneltian. Jakarta: Rineka Cipta.

Bungin, Burhan. 2007. Penelitian Kualitatif Komunitatif. Jakarta : PT Grafindo Persada.

EllyM.Setiadi. Usman Kolip. 2011. Pengantar Sosiologi Pemahaman Fakta dan Gejala Permasalahann Sosial: Teori, Aplikasi, dan Pemecahnya. Jakarta: Prenada Media Group

Irnawan, Alzaena Geanina. 2018. Privatisasi Sempadan Pantai Oleh Santrian Resort Hotel and Villas di PantaiSanur, Denpasar.
Capil Beach Grill\&Bar, D’Joglo Beach Bar\&Restaurant, The-Camplung Bar\&Restaurant, La-Plancha, Bali Juice-Park, Taris-Bali, dan Chiringuito Bar-Grill- Restaurant. 10(sepuluh) bisnis yang memakain area yang seharunya merupakan area untuk public/khalayak ramai. Aktivitas eksklusif ini juga member pengaruh kepada msyarakat yang tinggal disekitar yaitu masyarakat Desa Adat Smeinyak antara lain dahalm hal bahasa, cara berpakaian, bangunan tempat usaha, aliran music, makanan maupun minuman, dan lain sebagainya. Wisataan yang datang juga disuguhkan dengan atraksi yang bersifat kekinian/modern.

Kebijakan yang sudah di bentuk belumlah maksimal, dapat ditunjukkan ada pengaruh terjadi perubahan yang bersifat negative dimasyarakat dan terjadinyaa perubahan negatif kegunaan lingkungan dalamskala yang dapat terbilang luas dengan sebuahintensitas lama yang diakibatkan dari suatu usaha dan/atau kegiatan yang dilakukan di Wilayah Pesisir dan PulauPulau Kecil ini di dalam Undang-Undang Nomor 1 Tahun 2014 Pasal 233 yang bertuliskan Pariwisata boleh dilakukan di pulau-pulau kecil tetapi bukan pariwisata seperti di pantaii doublesix.

Pariwisata yang diperkenankan ialah berbasis konservasi atau eco-wisata. Dan perlu sanksi yang tegas terhadap tindakan privatisasi yang ada.

Laporan Penelitian LapanganIII:Fakultas Pariwisata, Universitas Udayana.

Islamy, IIrfan. 2003. Prinsip-prinsip Perumusan Kebijakan Negara. Jakarta: Bina Aksara.

Kristanto, Nyrdin H. Sistem Sosial-Budaya Di Indonesia. Semarang:Fakultas Sastra Universitas Diponogoro

Mahagangga, I., \& Oka, G. A. Suryawan, Ida Bagus. Anom, I Putu dan Kusumanegara, I Made. 2018. Evolusi Pariwisata di Indonesia, Turismemorfosis di Kabupaten Badung, Kabupaten Banyuwangi dan Kabupaten Luwu Timur.

Muhadjir, Neong. 1996. Metodologi Penelitian Kualitatif. Edisi Ke3. Rake Sarasin Yogyakarta

Narimawati, Umi. 2011. Metodologi Penelitian Kualitatif dan Kuantitatif: Teoridan Aplikasi. 
Novri Susan. 2010. Pengantar Sosiologi Konflik dan Isu-isu Konflik Kontemporer. Jakarta: Kencana Prenada Media Group.

Sanjiwani, Putri Kusuma. 2016. Pengaturan Hukum Terhadap Privatisasi Sempadan Pantai Oleh Pengusaha Pariwisata di Provinsi Bali. Jurnal Analisis Pariwisata, Vol. 16, No. 1, Hal. 29-34. Denpasar : Universitas Udayana.

Sipayung, Margaretha Ervina, 2016. Konflik Sosial Dalam Novel Maryam Karya Okky Madasari: Kajian Sosiologi Sastra. Jurnal Ilmiah Kebudayaan SINTESIS, Volume 10, Nomor 1. Yogyakarta :Sipayung Program Studi Sastra Indonesia, Universitas Sanata Dharma.

Sugiyono, 2010. Metode Penelitian Pendidikan Pendekatan Kualitatif, Kuantitatif dan R\&D. Bandung:Alfabeta.

Suryawan, I. B., \& Mahagangga, I. G. A. O. (2017). Penelitian Lapangan 1. Denpasar: Cakra Media dan Fakultas Pariwisata Universitas Udayana.

Wirawan. 2010. Konflik dan Manajemen Konflik: Teori, Aplikasi, danPenelitian. Jakarta: Salemba Humanika.

Peraturan Perundang-undangan

Anonim. 2016. Peraturan Presiden Republik Indonesia Nomor 26 Tahun 2016 tentang Bebas Visa. Jakarta: Kementerian Hukum dan Hak Azasi Manusia Republik Indonesia.

. 2003. Undang-Undang No 19 tahun 2003 TentangBadan Usaha Milik Negara. Jakarta.

. 2009. Undang-Undang No. 10 tahun 2009 TentangKepariwisataan. Jakarta.

2004. Undang-UndangRepublik Indonesia Nomor 32 Tahun 2004 tentang Pemerintahan Daerah. Jakarta:Kementrian Hukum dan Hak Azasi Manusia Republik Indonesia.

2013. Peraturan Daerah Kabupaten Badung Nomor 26 Tahun 2013 tentang Rencana Tata Ruang Wilayah Kabupaten Badungg tahun 2013-2033. Badung :Bupati Badung. 